\title{
Effect of Delayed Cassava Planting on Yields and Economic Returns of a Cassava-Groundnut Intercrop in the Democratic Republic of Congo
}

\author{
Thandar Nyi ${ }^{1,2, *}$, Monicah Mucheru-Muna², Christ Shisanya ${ }^{3}$, Jean-Paul Lodi Lama ${ }^{4}$, Patrick K. Mutuo ${ }^{5}$, Pieter \\ Pypers $^{6}$, Bernard Vanlauwe ${ }^{1}$ \\ ${ }^{1}$ International Institute of Tropical Agriculture (IITA), Nairobi, Kenya \\ ${ }^{2}$ Department of Environmental Sciences, Kenyatta University, Nairobi, Kenya \\ ${ }^{3}$ Department of Geography, Kenyatta University, Nairobi, Kenya \\ ${ }^{4}$ International Institute of Tropical Agriculture (IITA), Kinshasa, DR. Congo \\ ${ }^{5}$ International Centre for Tropical Agriculture (CIAT), Arusha, Tanzania \\ ${ }^{6}$ International Centre for Tropical Agriculture (CIAT), Nairobi, Kenya \\ *Corresponding author: nyi.thandar@gmail.com
}

Received April 08, 2014; Revised April 14, 2014; Accepted May 06, 2014

\begin{abstract}
Cassava intercropping is a common practice in sub-Saharan Africa. In terms of growth pattern, canopy development and nutrient demand, grain legumes are well suited for intercropping with cassava. Due to the interspecific competition for growth resources, the relative planting time of the component crops has been considered as one of the important management practices for intercropping system productivity. Little information exists on the effect of cassava planting time on yields and economic returns of a cassava-legume intercrop. This study investigated the effect of relative planting times of cassava on yields and economic returns of a cassava-groundnut intercrop. Researcher-managed, field trials were installed in Bas-Congo Province in two consecutive seasons using four different planting times of cassava after the groundnuts. The results indicated that cassava planting time did not affect both grain and biomass yields of groundnut. When cassava was planted 3 weeks after the groundnuts, cassava storage root yields were significantly $(P=0.029)$ decreased by 48 to $60 \%\left(9.3\right.$ to $\left.11.3 \mathrm{t} \mathrm{ha}^{-1}\right)$ over cassava planted at the same time as groundnut. The net revenue of cassava planted 3 weeks after the groundnut was significantly $(P=$ 0.002) decreased by about $70 \%$ over that of cassava planted at the same time or 2 weeks after the groundnuts. Maximum net revenue of $\$ 1877$ ha $^{-1}$ with a benefit-cost ratio of 2.42 was reported in the treatment of cassava planted at the same time. Benefit-cost ratio was favourable for the pure cassava (3.2 to 3.8) but not favourable for the pure groundnut. Cassava intercropping with groundnut had significantly $(P=0.019)$ lower profits than the pure cassava. The results suggest that cassava should be planted at the same time or not later than 2 weeks after the groundnuts to maximize yields and economic returns in a cassava-groundnut intercrop.
\end{abstract}

Keywords: BCR, grain yield, intercropping, $M R R$, relative planting time, storage root yield

Cite This Article: Thandar Nyi, Monicah Mucheru-Muna, Christ Shisanya, Jean-Paul Lodi Lama, Patrick K. Mutuo, Pieter Pypers, and Bernard Vanlauwe, "Effect of Delayed Cassava Planting on Yields and Economic Returns of a Cassava-Groundnut Intercrop in the Democratic Republic of Congo.” World Journal of Agricultural Research, vol. 2, no. 3 (2014): 101-108. doi: 10.12691/wjar-2-3-3.

\section{Introduction}

Intensive agriculture together with rapid population growth and limited nutrient inputs have resulted in declining soil fertility that leads to a gradual decline in per capita food production in sub-Saharan Africa [1]. In order to maintain soil fertility and crop yields, intercropping which has been a common practice of small-holder farmers is one of the existing options in crop production. Intercropping system is the cultivation of two or more crops in the same space during the same season which uses environmental resources efficiently better than the crops grown separately [2,3,4]. Besides improving soil fertility [5,6] and stabilizing higher yield [7], the benefits associated with intercropping are reducing risk of crop failure [8], decreasing disease severity [9], controlling weed pressure $[10,11,12]$ and achieving more efficient utilization of environmental resources relative to the pure cropping system $[13,14,15,16]$.

Cassava-based farming systems are particularly prevalent as cassava is one of the major staple foods widely grown in most sub-Saharan Africa countries [17]. Cassava, a widely-spaced, long duration crop is often intercropped with short duration crops such as cereals and grain legumes. Among intercrops, legumes have been considered to be compatible crops for intercropping with cassava [18] as they supply a sustainable amount of nitrogen $(\mathrm{N})$ into lower input agro-ecosystems [19]. 
Besides the advantages of transferring some $\mathrm{N}$ to the present crop and some residual $\mathrm{N}$ to the following crops [20], legumes grown in intercropping conserve the other nutrients through the return and crop residues decomposition [21]. Leguminous plants are also well suited with cassava in terms of nutrient demands since they need mostly phosphorus (P) and can get some required $\mathrm{N}$ from the nitrogen fixation through soil bacteria Rhizobia in their root nodule [22] whereas cassava extracts more potassium $(\mathrm{K})$ for storage in root production and $\mathrm{N}$ for leaf production [23,24]. According to [8] intercropping of cassava with legumes (cowpea, soybean, groundnut and common beans) could increase land equivalency ratios as compared to the pure crop. For instance, land equivalency ratios were increased by 50 to $73 \%$ in the cassava-cowpea intercrop [25] and 10 to $58 \%$ in the cassava-soybean intercrop [26]. Several authors have also reported that intercropping with legume crops did not show a significant effect on cassava yield relative to the pure cassava cropping system in a cassava-cowpea intercrop [27,28], a cassava-cowpea/groundnut intercrop [28] and a cassava-mungbean intercrop [29]. Among the various legume plants, groundnut (Arachis hypogaea L.) is one of the recommended legume crops for intercropping with cassava [31]. Intercropping with groundnut increases the productivity (land equivalent ratio of 1.27 to 1.85) [32]. The economic benefits could also be achieved by intercropping with groundnut under both rain-fed and irrigated conditions in the cassava-groundnut intercrop in Asia [33]. Cassava intercropping with groundnut also resulted in a positive response of cassava storage root yield and net income [34] as well as decreasing the soil erosion over the pure cassava stand [35,36].

On the other hand, agronomic practices such as plant densities, crop arrangement and relative planting times can increase productivity in cassava-legume intercropping systems [37]. Among these practices, the relative planting time of component crop could affect the yields of component crops [38,39,40,41], which has been attributed to the interspecific competition between the component crops for resources [38,42,43]. Delayed growth of cassava was also found in the cassava-groundnut intercrop due to the interspecific competition of resources such as light and nutrients [33]. Generally, labour can be spread more easily if the crops do not require planting at the same time. Thus, the relative planting time of component crops is an important management practice for crop yields and economic returns in the cassava-groundnut intercropping system. Nevertheless, the relative planting time of cassava has not been widely studied and not well documented in the cassava-groundnut cropping systems in Africa. Therefore, this study aimed to investigate the appropriate planting time of cassava to improve crop yields and economic returns in the cassava-groundnut intercropping system in DR. Congo.

\section{Materials and Methods}

\subsection{The Study Area}

Field trials were conducted in Mvuazi research station, Zenga ( $5^{\circ} 26^{\prime} 96^{\prime}$ ' S, 14 $54^{\circ}$ '67” E, $435 \mathrm{~m}$ above sea level) of the Bas-Congo province in Democratic Republic of
Congo (DR. Congo). The area receives on average 1300 $\mathrm{mm}$ of rain. The rainfall in the Bas-Congo province is bimodal with the first season $\left(1^{\text {st }}\right.$ season) lasting from October to mid-February, and the second season $\left(2^{\text {nd }}\right.$ season) lasting from early March to mid-May, followed by a short dry season ( $3^{\text {rd }}$ season). The growing period is about 290 days per year. The mean annual temperature is $25^{\circ} \mathrm{C}$ and the soil was classified as Haplic Acrisols [44]. Some selected characteristics of the top soil $(0-15 \mathrm{~cm})$ before sowing data are shown in Table 1.

Table 1. Selected physico-chemical soil properties in Zenga site

\begin{tabular}{|c|c|c|}
\hline Soil parameters & Units & Zenga \\
\hline Total soil organic carbon $\dagger$ & $\mathrm{g} \mathrm{kg}^{-1}$ & 31.2 \\
\hline Total N† & $\mathrm{g} \mathrm{kg}^{-1}$ & 1.13 \\
\hline Available P $\ddagger$ & $\mathrm{mg} \mathrm{P} \mathrm{kg}{ }^{-1}$ & 3.53 \\
\hline $\mathrm{pH}\left(\mathrm{H}_{2} \mathrm{O}\right)$ & & 6.11 \\
\hline ECEC§ & $\mathrm{cmol}_{\mathrm{C}} \mathrm{kg}^{-1}$ & 7.33 \\
\hline Exchangeable $\mathrm{K}^{+}$ & $\mathrm{cmol}_{\mathrm{C}} \mathrm{kg}^{-1}$ & 0.23 \\
\hline Exchangeable $\mathrm{Ca}^{2+}$ & $\mathrm{cmol}_{\mathrm{C}} \mathrm{kg}^{-1}$ & 4.23 \\
\hline Exchangeable $\mathrm{Mg}^{2+}$ & $\mathrm{cmol}_{\mathrm{c}} \mathrm{kg}^{-1}$ & 1.16 \\
\hline Clay & $\%$ & 22.1 \\
\hline Sand & $\%$ & 51.8 \\
\hline Silt & $\%$ & 26.1 \\
\hline
\end{tabular}

† Combustion method

‡Olsen P method (determined in a modified Olsen extract at $\mathrm{pH}$ 8.5)

$\S$ Effective Cation Exchange Capacity (determined by Atomic Absorption Spectroscopy)

Cassava is the main staple food in the study area, which is grown by all farmer households in the lowlands of BasCongo [45]. Farmers mostly intercrop cassava with grain legumes, especially groundnut, cowpea (Vigna unguiculata (L.) Walp.), common beans (Phaseolus vulgaris L.) and soybean (Glycine max). The cumulative rainfall during the experimental period in Zenga site is shown in Figure 1.

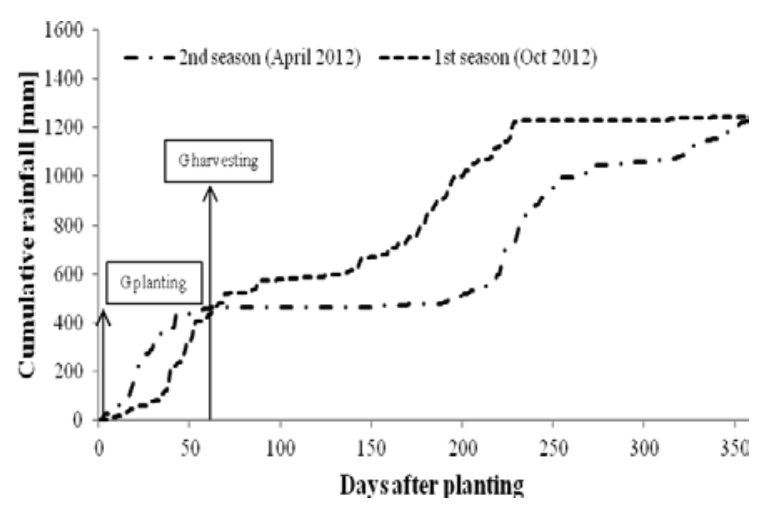

Figure 1. Cumulative rainfall during the experimental period. G refers to Groundnut. Cassava or groundnut planting and harvesting dates are indicated

\subsection{Trial Management and Establishment}

In April 2011, at the onset of $2^{\text {nd }}$ season, field trials were installed. The field trials were established following a randomized complete block design with three replicates. Plots measured $54 \mathrm{~m}^{2}$. In all plots, planting beds of $90 \mathrm{~cm}$ width were installed with a spacing of $90 \mathrm{~cm}$ between the beds. Two rows of cassava were planted per planting bed. Cassava was planted at a spacing of $90 \mathrm{~cm}$ x $90 \mathrm{~cm}$ interand intra-row, respectively. Groundnut was planted in two parallel lines within the planting bed between the two 
lines of cassava. Groundnut was planted at spacing of 30 cm x $20 \mathrm{~cm}$ inter- and intra-row, respectively; for both intercropped and pure groundnut stands. Cassava improved variety 'Nsansi' and groundnut improved variety 'JL 24' were used. Main treatments were cropping systems (pure and intercropped cassava), while sub treatments were the cassava planting time. The treatment details are shown in Table 2.

Table 2. Treatment structure for the determination of optimal planting time of cassava in the cassava-groundnut intercropping system during $1^{\text {st }}$ and $2^{\text {nd }}$ seasons in Zenga site

\begin{tabular}{lll}
\hline Cropping system & Cassava planting time & NPK fertilizer kg ha ${ }^{-1}$ \\
\hline $\begin{array}{l}\text { Cassava-groundnut } \\
\text { intercrop }\end{array}$ & $\begin{array}{l}\text { same time as the } \\
\text { groundnuts } \\
\text { 1 week after the } \\
\text { groundnuts } \\
\text { 2 weeks after the } \\
\text { groundnuts } \\
\text { 3 weeks after the } \\
\text { groundnuts }\end{array}$ & 100 (17 N: 17 P: 17 K) \\
& $\begin{array}{l}\text { - } \\
\text { Pure groundnut }\end{array}$ & 100 \\
\hline Pure cassava & $\begin{array}{l}\text { 1 week after the } \\
\text { groundnuts } \\
2 \text { weeks after the } \\
\text { groundnuts } \\
\text { 3 weeks after the } \\
\text { groundnuts }\end{array}$ & 50 \\
\hline
\end{tabular}

At the planting time NPK fertilizer was band applied to the groundnut plants whilst for cassava it was applied per the planting hole. Weed operations were done at 1, 3, 6 and 8 months after planting. Farmers were not allowed to pick cassava leaves during the growing period. The experiment was carried out in two seasons $\left(1^{\text {st }}\right.$ and $2^{\text {nd }}$ seasons of 2012) in Zenga site.

\subsection{Crop Measurements}

Two months after groundnut sowing, above ground biomass was collected from a $1 \mathrm{~m}$ strip within the net plot to determine the biomass yields of groundnut. Groundnut was harvested at full maturity from the net plot $\left(36 \mathrm{~m}^{2}\right)$; when pods had dried, the grains were collected. Biomass and grains were oven-dried $\left(65^{\circ} \mathrm{C}\right)$ for $48 \mathrm{~h}$ and weighed. Cassava was harvested at 12 months after planting. At harvesting, stem and storage root yields were determined. Subsequently, storage roots were divided into large tradable and small non-tradable storage roots, counted, and sub-sampled for determination of the dry matter (DM) content of the flesh (parenchyma) and peelings.

\subsection{Economic Analysis}

Economic analysis comprised calculation of total cost and total benefits, and benefit-cost ratios after adjusting the average yields i.e., the average yield was adjusted downward to $10 \%$ to reflect the difference between the experimental yield and the farmer yield (without the researchers' involvement) from the same treatment [46]. Total benefits were estimated using the unit prices for groundnut grain yield and fresh storage root yield of cassava at the local markets in the study site (2.01 USD $\mathrm{kg}^{-1}$ of groundnut grains in both seasons and 0.12 USD kg${ }^{1}$ and $0.1 \mathrm{USD} \mathrm{kg}^{-1}$ of cassava tradable root yields in $2^{\text {nd }}$ and $1^{\text {st }}$ seasons, respectively). Total costs included input costs (seed, cutting and fertilizer) and labour costs (land preparation, planting, weeding and harvesting) in the different treatments. Groundnut grain price was used for seed since most farmers recycle seed. Cassava stems were valued both as an input (planting material) and as produce at $\$ 0.04 \mathrm{~m}^{-1}$. Economic analysis did not take leaf production into account. The price of NPK compound fertilizer was obtained from the local market in the study site (100 USD per $50 \mathrm{~kg}$ bag). The labour was valued at a wage of 2.7 USD for a 6 hour working day. An exchange rate of 920 Congolese francs to 1 USD (2012) was used. The benefit-cost ratios of the various treatments were calculated as the ratio of total benefits over total costs and were considered favourable when exceeding 2 invested by the farmer [46]. A sensitivity analysis was conducted for selected treatments. Cassava root and groundnut grain prices were decreased by up to $50 \%$ or increased by up to $150 \%$ to determine changes in net benefits.

\subsection{Statistical Analysis}

Analysis of variance was conducted to determine the effects of different treatments using a mixed linear model (MIXED procedure, SAS Institute Inc., 2009). In the mixed model analysis, the treatments of cropping systems and cassava planting time were used as fixed factors and 'replicate' within season were considered as random factors. The effects of the various treatments were compared by computing least square means and standard errors of difference (SED). Significance of difference was evaluated at $P<0.05$.

\section{Results and Discussion}

\subsection{Groundnut Grain Yields}

The relative planting time of cassava had no significant influence on the grain yields of groundnut in the cassavagroundnut intercrop in both $2^{\text {nd }}$ and $1^{\text {st }}$ seasons (Figure 2).

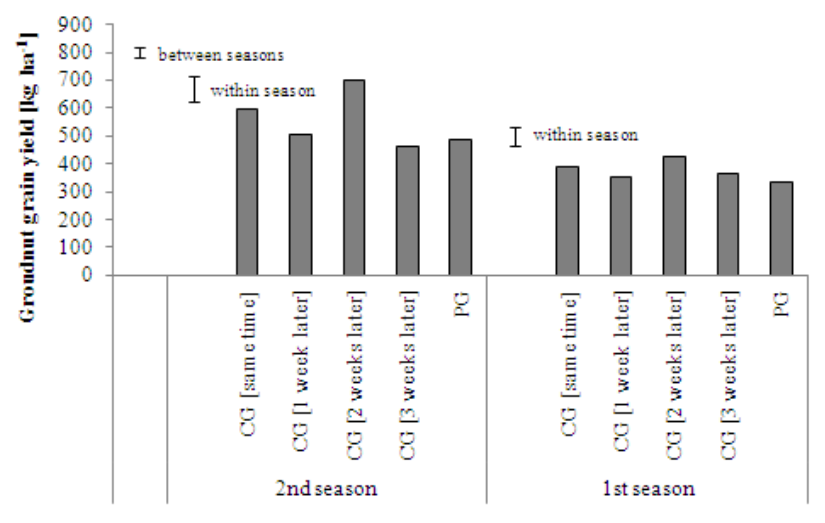

Figure 2. Groundnut grain yields as affected by the relative planting time of cassava in both seasons. Error bars represent standard error of difference (SED) for comparisons of all treatments. CG and PG refer to the cassava-groundnut intercrop and the pure groundnut, respectively

Maximum grain yields (699 $\mathrm{kg} \mathrm{ha}^{-1}$ and $426 \mathrm{~kg} \mathrm{ha}^{-1}$ ) were recorded in the treatment of cassava planted 2 weeks after the groundnuts in $2^{\text {nd }}$ and $1^{\text {st }}$ seasons, respectively. The grain yields were only significantly $(P=0.01)$ different between the treatments of cassava planted 2 weeks and 3 weeks after the groundnuts in $2^{\text {nd }}$ season. The grain yield of groundnut was not significantly influenced by intercropping with cassava in both seasons except in 
$2^{\text {nd }}$ season where a significant $(P=0.015)$ difference on grain yields between the cassava-groundnut and the pure cassava planted 2 weeks after the groundnuts was found. There was a significant $(P=0.0007)$ difference on the groundnut grain yields between the two seasons.

Though there was no effect of cassava planting time on groundnut grain yield in the cassava-groundnut intercrop, other studies [38,39,40,41] have reported the decreased grain yields as a result of relative planting time of the crop. This was attributed to the interspecific competition between the two crops for resources $[38,42,43]$. When cassava was planted 2 weeks after the groundnuts in $2^{\text {nd }}$ season, the grain yield was higher over the cassava planted 3 weeks after the groundnuts. This could be attributed to higher rainfall in the period of third week than fourth week of April, 2011. The result implies that the intercropping with groundnut had no influence on groundnut grain yield relative to the pure groundnut. Since cassava has a slow early growth $[28,47,48,49]$, resulting in slow canopy formation [50,51] and groundnut matures after attaining maximum canopy development of cassava, there is a competition gap between the periods when each of the component crops is making critical demands for growth resources such as light, water and nutrients [52]. This could also be contributed by different growth habits between the two crops where groundnut is low growing and cassava has an erect type. Conversely, intercropping with cassava had a significant influence on groundnut grain yield in the cassava-groundnut intercrop $[18,53]$. The $2^{\text {nd }}$ season produced more grain yield, about 28 to $54 \%$ higher than $1^{\text {st }}$ season. This could probably be due to lower rainfall distribution in October, 2011 resulting in relatively lower germination percentage of groundnut (about $21 \%$ ) relative to April, 2011. Grain yield of groundnut was lower than the range of yields attained under farmers' field conditions in Africa which were reported by [54] to be an estimated $700 \mathrm{~kg} \mathrm{ha}^{-1}$. These low yields could be attributed to high weed pressure, pests and diseases and poor structure of the soil in the study site, at the Bas-Congo, DR. Congo [55]. This might also be due to the insufficient amount of P (8.6 $\left.\mathrm{kg} \mathrm{ha}^{-1}\right)$ from NPK fertilizer applied for the groundnut production in Zenga site. Another explanation for this low yield might probably be the insufficient amount of Ca $\left(5 \mathrm{~kg} \mathrm{ha}^{-1}\right)$ from NPK fertilizer for groundnut production.

\subsection{Groundnut Biomass Yields}

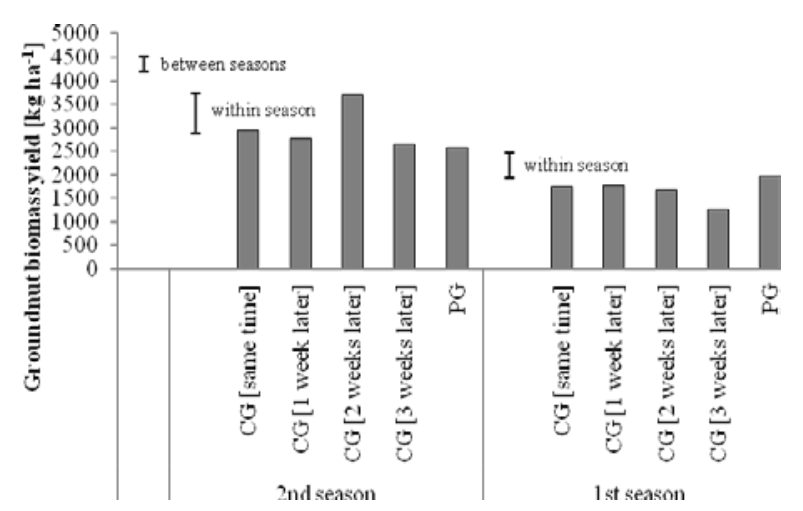

Figure 3. Groundnut biomass yields as affected by the relative planting time of cassava in both seasons. Error bars represent standard error of difference (SED) for comparisons of all treatments. CG and PG refer to the cassava-groundnut intercrop and the pure groundnut, respectively
No significant effect of cassava planting time on the biomass yields of groundnut in the cassava-groundnut intercrop was found in both seasons (Figure 3).

Maximum biomass yields (3700 $\mathrm{kg} \mathrm{ha}^{-1}$ and $1775 \mathrm{~kg}$ $\mathrm{ha}^{-1}$ ) were recorded in the cassava planted 2 weeks after the groundnuts in $2^{\text {nd }}$ season and in the cassava planted 1 week after the groundnuts in $1^{\text {st }}$ season, respectively. The intercropping with groundnut at all cassava planting times had no significant influence on groundnut biomass yields relative to the pure groundnut in both seasons. The biomass yield of groundnut was significantly $(P=0.004)$ higher (almost double) in $2^{\text {nd }}$ season compared to $1^{\text {st }}$ season.

Results from this study showed that intercropping with cassava had no influence on groundnut biomass yield in the cassava-groundnut intercrop. It can be assumed that the relative planting time of cassava used in this study might not have reached the interspecific competition for resources such as space, light, moisture, nutrient, etc. In contrast, the relative planting time of colocasia had influence on the biomass yield of rice in the colocasia-rice intercrop [40]. The failure of planting time to affect groundnut yields could be attributed to the slow early development of cassava [28, 47, 48] which might not reach the interspecific competition for resources (space, light, moisture and nutrients) with the groundnut crop. This might also be due to the suitable compatibility of the two crops as intercrops due to the wide maturity gap. This is in line with the previous study in the cassava-cowpea intercrop [28]. Conversely, intercropping with cassava had a significant influence on the biomass yields of Flemingia in the cassava-Flemingia intercrop [36].

\subsection{Cassava Storage Root Yields}

There was a significant $(P=0.037)$ effect of the relative planting time of cassava in both seasons (Figure 4).

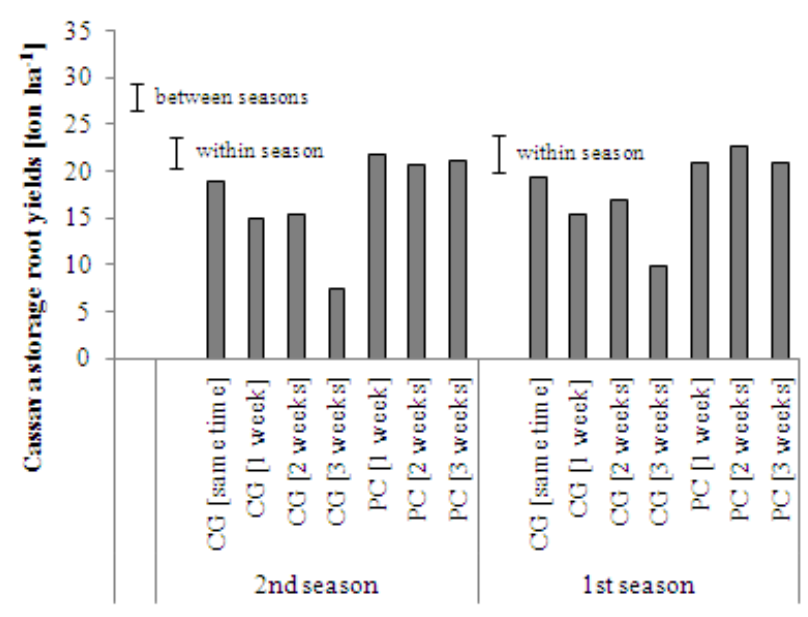

Figure 4. Cassava root yields as affected by the relative planting time of cassava in both seasons. Error bars represent standard error (SED) of difference for comparisons of all treatments. CG and PG refer to the cassava-groundnut intercrop and the pure groundnut, respectively

When cassava was planted 3 weeks after the groundnuts, the storage root yields were significantly $(P=0.037$ and $P$ $=0.042)$ decreased by $48 \%$ and $60 \%$ (9.3 to $11.3 \mathrm{t} \mathrm{ha}^{-1}$ ) in $2^{\text {nd }}$ and $1^{\text {st }}$ seasons, respectively, relative to cassava planted at the same time as groundnut. For the pure cassava cropping system, there was no significant effect of cassava planting time on cassava storage yields in both 
seasons. The effect of intercropping with groundnut on cassava storage root yields was not observed in both seasons. The storage root yield was only significantly $(P=$ 0.019 and $P=0.001)$ decreased by $64 \%$ and $73 \%$ (10.9 to $13.6 \mathrm{t} \mathrm{ha}^{-1}$ ) in the cassava intercrop 3 weeks after the groundnut as compared to the relative treatment of pure cassava in $2^{\text {nd }}$ and $1^{\text {st }}$ seasons, respectively. There were no significant differences on the storage root yields between the two seasons.

Cassava planted 3 weeks after the groundnut significantly decreased cassava storage root yields as compared to cassava planted at the same time as groundnut in the cassava-groundnut intercrop, probably due to the interspecific competition for growth resources (space, moisture and nutrients) between the two crops [56] and shading by groundnut plants to cassava when cassava was planted 3 weeks after the groundnuts. Cassava yields could be considerably decreased if the intercrop was planted earlier than cassava, creating strong interspecific competition for growth resources at a time when cassava was still a weak competitor [57]. The results indicate that cassava can be planted at the same time or not later than 2 weeks after the groundnut without affecting the storage root yields in the cassava-groundnut intercrop. Intercropping with groundnut had no influence on the storage root yields in the cassava-groundnut intercrop. The yields of the main crop and its intercrop would not be affected by their association where there is a competition gap between the periods when each of the component crops has critical demands for growth resources [51]. This could be due to the fact that groundnut, a short-duration crop (90 days) matured just after the maximum canopy development of cassava and harvested earlier before an increase rate of storage root bulking process in the cassava crop. The results of this study suggest that the presence of groundnut in the cassava-groundnut intercrop had no negative effect on the root yields of cassava when cassava was planted at the same time or not later than 2 weeks after the groundnuts.

\subsection{Cassava Stem Yields}

In the cassava-groundnut intercrop, the relative planting time of cassava had no significant effect on the stem yields of cassava in both $2^{\text {nd }}$ and $1^{\text {st }}$ seasons (Figure 5 ).

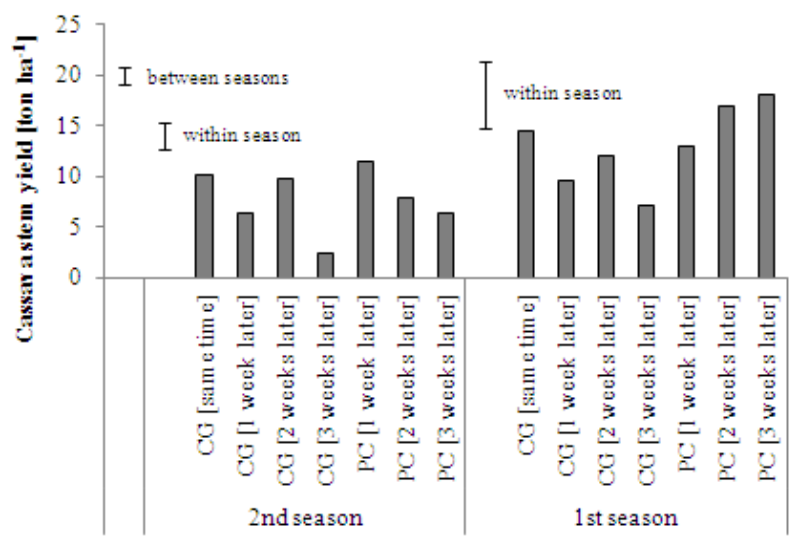

Figure 5. Cassava stem yields as affected by the relative planting time of cassava in both seasons. Error bars represent standard error of difference (SED) for comparisons of all treatments. CG and PG refer to the cassava-groundnut intercrop and the pure groundnut, respectively
The lowest stem yields (2.5 and $\left.7 \mathrm{t} \mathrm{ha}^{-1}\right)$ were recorded in the cassava planted 3 weeks after the groundnuts in $2^{\text {nd }}$ and $1^{\text {st }}$ seasons, respectively. In the pure cassava cropping system, the planting time of cassava had no significant effect on the stem yields in both seasons. No significant difference on the stem yields was found between the treatments of pure cassava and the relative treatments of cassava intercropping with groundnut in both seasons. The result indicates that intercropping with groundnut had no influence on the stem yield of cassava. This might be due to the different growing habits of the two crops while cassava has erect growth and groundnut is low growing. In contrast, the stem yields of petiole were significantly decreased by intercropping with legumes as compared to the pure cassava [58]. Planting cassava in $1^{\text {st }}$ season gave higher stem yields by about $87 \%$ than planting in $2^{\text {nd }}$ season. This difference might be due to higher rainfall in $2^{\text {nd }}$ season than that of $1^{\text {st }}$ season (Figure 1 ) or weed pressure.

\subsection{Economic Analysis}

In the cassava-groundnut intercrop, cassava planted 3 weeks after the groundnuts was less profitable as it resulted in a significant $(P=0.002)$ decrease in both total and net benefits (1226 to $1351 \mathrm{USD} \mathrm{ha}^{-1}$ ) as compared to the treatment of cassava planted at the same time or 2 weeks after the groundnut (Table 3 ). This reduced benefit was attributable to the negative effect on both cassava root yield and groundnut grain yield.

Table 3. Economic analysis, including total benefits (TC), total costs (TB), net benefits (NB) and benefit-cost ratio (BCR), as affected by the relative planting time of cassava in both seasons in Zenga site

\begin{tabular}{ccccc}
\hline Treatment & TB & TC & NB & BCR \\
\cline { 2 - 5 } & ------- & USD ha $^{-1}$ & ------- & \\
\hline CG [same time] & 3269 & 1311 & 1898 & 2.4 \\
CG [1 week] & 2689 & 1311 & 1319 & 2.0 \\
CG [2 weeks] & 3143 & 1311 & 1773 & 2.3 \\
CG [3 weeks] & 1918 & 1311 & 547 & 1.4 \\
PG [same time] & 791 & 704 & 87 & 1.1 \\
PC [1 week] & 3015 & 801 & 2214 & 3.8 \\
PC [2 weeks] & 2675 & 801 & 1875 & 3.3 \\
PC [3 weeks] & 2562 & 801 & 1760 & 3.2 \\
SED (Treatment) & $376 * * *$ & & $368 * * *$ & $0.4 * *$ \\
\hline
\end{tabular}

SED $=$ standard error of difference. $* * *=P<0.001$. CG, PG and PC mean the cassava-groundnut intercrop, the pure groundnut and the pure cassava, respectively.

When cassava was planted 3 weeks after the groundnuts, benefit-cost ratio (BCR) was unfavorable (BCR less than $\left.\$ 2 \$^{-1}\right)$ and significantly $(P=0.0193$ and $P=0.013)$ decreased by 39 to $41 \%$ as compared to the treatments of cassava planted at same time or 2 weeks after the groundnuts, respectively. The BCR was not favourable for the pure groundnut cropping system due to the low grain yields of groundnut. In the pure cassava cropping system, cassava planting time had no significant effect on both total and net benefits. The BCR was favourable (\$ 3.2 to $3.8 \$^{-1}$ ) in all treatments, indicating that the pure cassava cropping system is profitable in the study area. The intercropping with groundnut was significantly $(P=0.023)$ less profitable relative to the pure cassava cropping due to lower revenue obtained from the groundnut crop and 
higher cost of production. However, the results of previous studies revealed that the intercropping systems were more profitable than the pure stands in the cassavagroundnut intercrop [18], in the sorghum-groundnut intercrop [59] and in the pigeonpea-maize intercrop [60].

A sensitivity analysis is presented for evaluating the effect of changes in crop prices on the net benefits. Up to the current groundnut grain price (2.01 USD kg-1), net benefits for the PC [1 week later] treatment remained the largest shown in Figure 6.

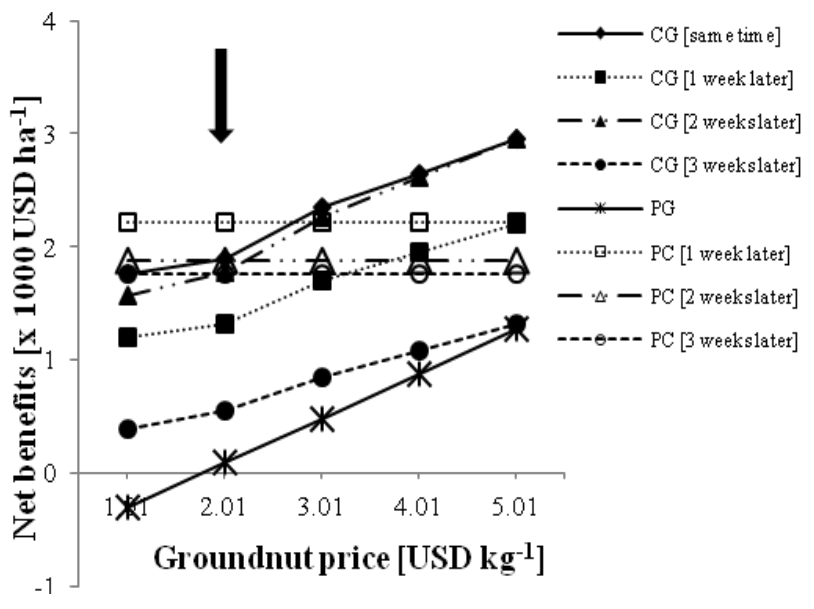

Figure 6. Sensitivity analysis evaluating the effect of changes in groundnut grain on the net benefits. Arrows indicate the current groundnut and cassava prices

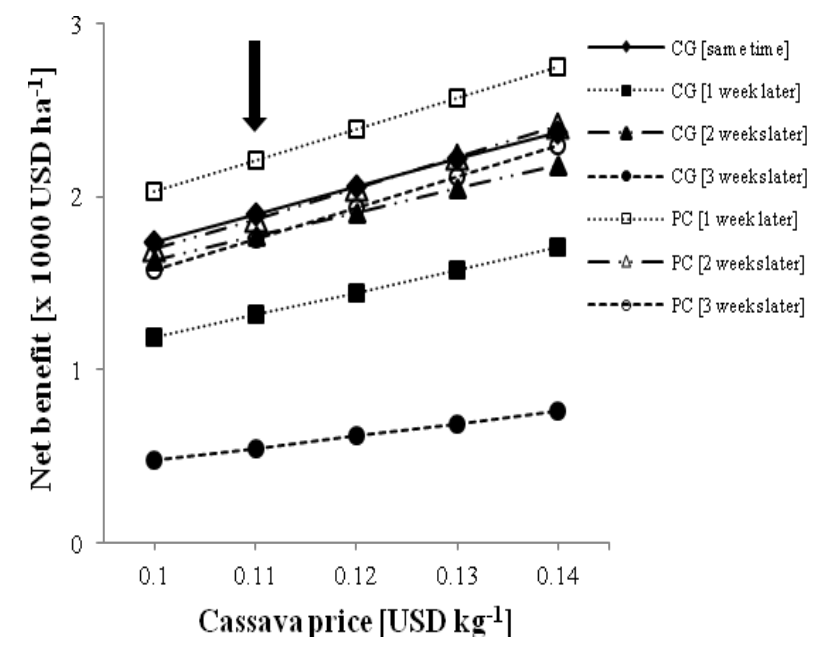

Figure 7. Sensitivity analysis evaluating the effect of changes in cassava root prices on the net benefits. Arrows indicate the current groundnut and cassava prices

When cassava planted at same time or 2 weeks after the groundnuts, net benefits increased (438 to 1778 USD ha $^{-1}$ ) if the grain price would change to $4.01 \mathrm{USD} \mathrm{kg}^{-1}$ relative to the pure cassava cropping system. This could be attributed to the additional profits of groundnut in the cassava-groundnut intercrop. A further increase of the grain price (5.01USD $\mathrm{kg}^{-1}$ ) would result in an increase of net benefits in the cassava-groundnut intercrop. This indicates that farmer will get a profit by the cassava intercropping with groundnut if the grain price is $>3.01$ USD $\mathrm{kg}^{-1}$. However, net benefits remained the lowest when cassava planted later than 3 weeks after the groundnuts in all price changes, indicating that planting of cassava at 3 weeks after planting was the lowest profit in the cassava-intercropping system due to the low grain yields. In all cassava root price changes, the PC [1 week later] treatment gave the largest net benefit (Figure 7).

Even though cassava price would increase up to 0.14 USD $\mathrm{kg}^{-1}$, the cassava intercropping with groundnut did not result in an increase of net benefits as compared to the pure cassava cropping system. This indicates that farmers should grow cassava alone as there was no additional benefit from the cassava intercropping with the groundnuts.

\section{Conclusion}

The results of this study show that it is a disadvantage to intercrop cassava 3 weeks after the groundnuts. This is associated with a lower cassava storage root yield, resulting in a lower profit in the cassava-groundnut intercrop. However, the relative planting time of cassava had no significant influence on the yields of groundnut in the cassava-groundnut intercrop. The maximum profit was obtained when cassava was planted at the same time as groundnut. It can be therefore concluded that farmers should plant cassava at the same time or not later than 2 weeks after the groundnuts in the cassava-groundnut intercrop. Based on the present data, farmers should grow cassava alone because the intercropping system does not give the additional benefits under current market conditions.

\section{Acknowledgement}

The authors wish to thank Jean-Jacques Nitmfuidi for his assistance with the field trials and the farmer groups for their keen participation. This work was funded by the Belgian Directorate General of Development Cooperation, as part of their project 'Enhancing the resilience of agroecosystems in Central Africa: a strategy to revitalize agriculture through the integration of natural resource management coupled to resilient germplasm and marketing approaches', one of the three projects of CIALCA, the Consortium for Improving Agricultural Livelihoods in Central Africa (www.cialca.org).

\section{References}

[1] Kang, B.T, Introduction to alley farming, in Tripathi, B.R., and Psychas, P.J, The AFNETA alley farming training manual: Source book for alley farming research. Vol. 2, IITA, 1992.

[2] Ofori, F., and Stern, W.R, "Cereal-legume intercropping systems," 1987 in Rydberg, N.T. and Milberg, P., Adv. Agron., 41: 41-90. 2000.

[3] Ghosh, P.K., Manna, M.C., Bandyopadhyay, K.K., Ajay, Tripathi, A.K., Wanjari, R.H., Hati, K.M., Misra, A.K., Acharya, C.L., and Subba Rao, A., "Interspecific interaction and nutrient use in soybean/sorghum intercropping system,” Agron. J., 98. 1097-1108. July 2006.

[4] Sobkowicz, P, "Competition between triticale (Tritico scalewitt) and field beans (vicia faba var minorl) in additive intercrops," Plant Soil Environ., 52. 42-54. Feb. 2006.

[5] Shen, Q.R., and Chu, G.X, "Bi-directional $\mathrm{N}$ transfer in the intercropping system of peanut with rice cultivated in aerobic soil,” Biol. Fertil. Soils, 40, 81-87. Jul. 2004.

[6] Dahmardeh, M., Ghanbari, A., Syahsar, B.A., and Ramrodi, M, "The role of intercropping maize (Zea mays L.) and cowpea 
(Vigna unguiculata L.) on yield and soil chemical properties,” Afr. J. Agric. Res., 5. 631-636. April 2010.

[7] Dapaah, H.K., Asafu-Agyei, J.N., Ennin, S.A., and Yamoah, C.Y, "Yield stability of cassava, maize, soybean and cowpea intercrops,” J. Agric. Sci., 140, 73-82. Feb. 2003.

[8] Mutsaers, H.J.W., Ezumah, H.C., and Osiru, D.S.O, "Cassavabased intercropping: a review,” Field Crops Res., 34(3). 431-457. Sept. 1993.

[9] Zinsou, V., Wydra, K., Ahohuendo, B., and Hau, B, "Genotypeenvironment interactions in symptom development and yield of cassava genotypes in reaction to cassava bacterial blight," European J. Plant Patholog., 111(3). 217-233. March 2005.

[10] Hernández, A., Ramos, R., and Sánchez, J, "Spacing and timing of intercropping cassava and beans: land equivalency ratio," Agronomica Mesoamericana, 10(11). 63-66. 1999.

[11] Hernández, A., Ramos, R., Sánchez, J, and Rodríguez, O., "Evaluation of weed control in a cassava-bean intercropping system,” Agronomica Mesoamericana, 10. 67-71. 1999.

[12] Amanullah, M.M., Somasundaram, E., Vaiyapuri, K., and Sathyamoorthi, K, "Intercropping in cassava-a review," Agric. Rev., 28. 179-187. 2007.

[13] Francis, C.A, "Biological efficiency in multiple cropping systems,” in Brady, N.C. Adv. Agron. 41, 1-42. 1989.

[14] Li, L., Tang, C., Rengel, Z., and Zhang, F.S, “Chickpea facilitates phosphorus uptake by intercropped wheat from an organic phosphorus source,” J. Plant Soil, 248. 297-303. Jan. 2003.

[15] Zhang, F., and Li, L, "Using competitive and facilitative interactions in intercropping systems enhances crop productivity and nutrient-use efficiency," Plant Soil, 248, 305-312. Jan. 2006.

[16] Li, L., Sun, J., Zhang, F., Guo, T., Bao, X., Smith, F.A., and Smith, S.E, "Root distribution and interactions between intercropped species,” Oecologia, 147(2). 280-290. March 2006.

[17] Mkamilo, G.S., and Jeremiah, S, "Current status of cassava improvement programme in Tanzania," in Afri. Crop Sci. Conference Proceedings, 7. 1311-1314. 2005.

[18] Polthanee, A., Wanapat, S., Wanapat, M., and Wachirapokorn, C, Cassava-Legumes intercropping: A potential food-feed system for dairy farmers, in International Workshop on Current Research and Development on Use of Cassava as Animal Feed, Khon Kaen University, Thailand, July 2001, 23-24.

[19] Fustec, J., Lesuffleur, F., Mahieu, S., and Cliquet, J.B, "Nitrogen rhizodeposition of legumes. A review,” Agron. Sustain. Develop., 30. 57-66. Jan. 2010.

[20] Adu-Gyamfi, J.J., Myaka, F.A., Sakala, W.D., Odgaard, R., Vesterager, J.M., and Høgh-Jensen, H, "Biological nitrogen fixation and nitrogen and phosphorus budgets in farmer-managed intercrops of maize-pigeonpea in semi-arid southern and eastern Africa,” Plant and soil, 295. 127-136. Feb. 2007.

[21] Rahman, M.M., Amano, T., and Shiraiwa, T, "Nitrogen use efficiency and recovery from $\mathrm{N}$ fertilizer under rice-based cropping systems,” Australian J. Crop Sci., 3. 336-351. Jul. 2009.

[22] Giller, K.E, Nitrogen fixation in tropical cropping systems, CABI, 2001.

[23] Howeler, R. H, Cassava mineral nutrition and fertilization, in Hillocks, R.J., Thresh, J.M., and Bellotti, A, Cassava: Biology, production and utilization, CABI, 2002, 115-147.

[24] Carsky, R.J., and Toukourou, M.A, "Identification of nutrients limiting cassava yield maintenance on a sedimentary soil in southern Benin, West Africa,” Nutreint Cycling in Agroecosys., 71. 151-162. Jul. 2005.

[25] Mba, A., and Ezumah, H.C, Cassava/cowpea intercropping International institute of agriculture (IITA) report for 1984, Ibadan, Nigeria, 1985, 175-176.

[26] Tsay, J.S., Fukai, S., and Wilson, G.L, "Intercropping with soybean cultivars of varying maturities,” Field Crops Res., 19. 211-225. Jul. 1988

[27] Sikirou, R., and Wydra, K, "Persistence of Xanthomonas axonopodis pv. Vignicola in weeds and crop debris and identification of Sphenostylis stenocarpa as a potential new host," Eur. J. Plant Pathol. 110. 939-947. April 2004.

[28] Njoku, D.N., and Muoneke, C.O, "Effect of cowpea planting density on growth, yield and productivity of component crops in cowpea/cassava intercropping system," J. Tropical Agriculture, Food, Environment and Extension, 7(2). 106-113. May 2008. Mason, S.C., Leihner, D.E., and Vorst, J.J, "Cassava-cowpea and cassava-peanut intercropping. I. Yield and land use efficiency," Agron. J. 78. 43-46. 1986.
[29] Mason, S.C., Leihner, D.E., and Vorst, J.J, “Cassava-cowpea and cassava-peanut intercropping. I. Yield and land use efficiency,” Agron. J. 78. 43-46. 1986.

[30] Polthanee, A., and Kotchasatit, A, "Growth, yield and nutrient content of cassava and mungbean grown under intercropping," Pak. J. Biol. Sci. 2(3). 871-876. 1999.

[31] Nayar, T.V.R., Kabeerathumma, S., Potty, V.P., and Mohankumar, C.R, Recent progress in cassava agronomy research, in Cassava breeding, Agronomy and farmer participatory research in Asia, in Proceedings of the Fourth Regional Workshop, held in Trivandrum, Kerala, India, 1993, Nov. 2-6.

[32] Osiru, D.S.O., and Hahn, S.K, Evaluation of cassava genotypes for intercropping systems, Root, Tuber and Plantain Improvement Program, Annual Report for 1987, IITA, Ibadan, Nigeria, 1998, 15-18.

[33] Prabhakar, M., and Nair, G.M, "Effect of agronomic practices on growth and productivity of cassava-groundnut intercropping system,” J. Root Crops, 189(1). 26-31. 1992, in Howeler, R.H, Cassava breeding, agronomy research and technology transfer in Asia, in Proceedings of the Fourth Regional Workshop, Trivandrum, Kerala, India, 1993, Nov. 2-6.

[34] Reddy, M.S., Floyd, C.N., and Willey, R.W, Groundnut in intercropping systems, in Proceedings of the International Intercropping Workshop, India, 1979, Jan. 10-13, 133-142.

[35] Tongglum, A., Pornpromprathan, V., Nual-on, T., and Howeler, R.H, Recent progress in cassava agronomy research in Thailand, in Howeler, R.H, Cassava breeding, agronomy and farmer participatory research in Asia, Proceedings of the fifth Regional Workshop, held in Danzhou, Hainan, China, 1996, Nov. 3-8.

[36] Dung, N., Ledin, I., and Mui, N.T, “Intercropping cassava (Manihot esculenta Crantz) with Flemingia (Flemingia macrophylla): effect on biomass yield and soil fertility,” Livestock Res. Rural Develop., 17(1). 1-13. 2005.

[37] Pypers, P., Sanginga, J.M, Kasereka, B., Walangululu, M., and Vanlauwe, B, "Increased. productivity through integrated soil fertility management in cassava-legume intercropping systems in the highlands of Sud-Kivu, DR Congo,” Field Crops Res., 120, 76-85. Sept. 2011.

[38] Francis, C.A., Prager, M., and Tejada, G, "Effect of relative planting dates in bean (Phaseolus vulgaris L.) and maize (Zea mays L.) intercropping patterns,” Field Crops Res., 5. 45-54. 1982.

[39] Agyekum, E, The effect of plant density and relative time of planting on colocasia/rice intercropping system, Master thesis, The Department of Crop Science, College of Agriculture and Natural Resources, Kumasi, Ghana, 2004.

[40] Addo-Quaye, A.A., Darkwa, A.A., and Ocloo, G.K, "Growth analysis of component crops in a maize-soybean intercropping system as affected by time of planting and spatial arrangement," ARPN J. Agric. Bio. Sci., 6(6). 34-44. Jun. 2011.

[41] Addo-Quaye, A.A., Darkwa, A.A., and Ocloo, G.K, "Yield and productivity of component crops in a maize-soybean intercropping system as affected by time of planting and spatial arrangement," ARPN J. Agric. Bio. Sci., 6(9). 50-57. Sept. 2011.

[42] Caballero, R., Goicoechea, E.L., and Hernaiz, P.J, "Forage yields and quality of common vetch and oat sown at varying seeding ratios and seeding rates of common vetch,” Field Crops Res., 41. 135-140. May 1995.

[43] Assefa, G., and Ledin, I, "Effect of variety, soil type and fertilizer on the establishment, growth, forage yield, quality and voluntary intake by cattle of oats and vetches cultivated in pure stands and mixtures,” Animal Feed Sci. and Tech., 92. 95-111. Jul. 2001.

[44] FAO/IIASA/ISRIC/ISSCAS/JRC 2009. Harmonized World Soil Database (version 1.1). Italy, FAO, Rome and IIASA, Laxenburg, 2009.

[45] Pypers, P., Bimponda, W., Lodi-Lama, J.P., Lele, B., Mulumba, R., Kachaka, C., Boecky, P., Merckx, R., and Vanlauwe, B, "Combining mineral fertilizer and green manure for increased, profitable cassava production,” Agron. J., 104: 178-187. 2012.

[46] CIMMYT, From agronomic data to farmer recommendations: An economics training manual, Completely revised edition. Mexico, D.F, 1988, 79 .

[47] Ikeorgu, J.E.G, Intercropping cassava and three groundnut species in the derived savanna zone of Nigeria, in Tropical Grain Legume Bulletin no. 35, 1988.

[48] Muleba, N.E., Dabire, C., Suh, J.B., and Drabo, I, Technologies from cowpea production based on genetic and environmental manipulations in the semi-arid tropics, Publication of the SemiArid Food Grain Research and Development Agency (SAFGRAD) 
of the Scientific, Technical and Research Commission of OUA, Burkina Faso, 1997, 56.

[49] Lebot, V, Tropical root and tuber crops: cassava, sweet potato, yams, aroids, CABI, 2009.

[50] Howeler, R.H, Cassava agronomy research in Asia - an overview 1993-1996, in Cassava breeding, Agronomy and farmer participatory research in Asia. Proceedings of the Fifth Regional Workshop, Danzhou, Hainan, China. 3-8 Nov. 1996. CIAT, Cali, Columbia, 1998, 335.

[51] Putthacharoen, S., Howeler, R.H., Jantawat, S., and Vichukit, V, "Nutrient uptake and soil erosion losses in cassava and six other crops in a Psamment in eastern Thailand,” Field Crops Res., 57. 113-12. May 1998.

[52] Trenbath, B.R, "Biomass productivity of mixtures," in Brady, N.C, Adv. Agron. 26, 177-210. 1974

[53] Ikeorgu, J.E.G., Ezumah, H.C., and Wahua, T.A.T, "Productivity of species in cassava/maize/okra/egusi melon complex mixtures in Nigeria,” Field Crops Res., 21(1). 1-7. Jun. 1989.

[54] Freman, H.A., Nigam, S.N., Kelley, T.G., Ntare, B.R., Subrahmanyam, P., and Boughton, D, The world groundnut economy: facts, trends and outlook, Patancheru 502 324, Andhra
Pradesh, India: International Crops Research Institute for the Semi-Arid Tropics, 1999, 52.

[55] CIALCA, Consortium for Improved Agriculture-based Livelihoods in Central Africa, Final Report Phase I - CIALCA. January 2006-December 2008. Aug. 2009. Available: www.cialca.org/.

[56] Hillocks, R. J., Thresh, J. M., and Bellotti, A. (Eds.). Cassava: biology, production and utilization., CABI, 2002.

[57] Leihner, D, Agronomy and cropping system, in Hillocks, R.J., Thresh, J.M., and Bellotti, A, Cassava: Biology, production and utilization, CABI, Oxon, 2002, 91-113.

[58] Borin, K., and Frankow-Lindberg, B.E, "Effects of legumescassava intercropping on cassava forage and biomass production," J. Sustain. Agri., 27(2). 139-151. 2005

[59] Langat, M.C., Okiror, M.A., Ouma, J.P., and Gesimba, R.M, “The effect of intercropping groundnut (Arachis hypogea L.) with sorghum (Sorghum bicolor L. Moench) on yield and cash income," Agricultura Tropica et Subtropica, 39(2). 87-91. 2006.

[60] Egbe, M.O., and Idoko, J.A, "Evaluation of pigeonpea Genotypes for intercropping with maize and sorghum in Southern Guinea Savanna: Economic Benefits,” Int. J. Agri. Forest., 2(1). 108-114. 2012. 